\title{
Antynomie ludzkiej kondycji w Marchołcie Jana Kasprowicza
}

$\mathrm{Na}$ oryginalny dramaturgiczny dorobek Kasprowicza składa się siedem tekstów, rozpiętych na przestrzeni niespełna trzydziestu lat. Ilościowo jest to niewiele, zwłaszcza na tle całokształtu twórczości literackiej poety, niemniej widoczne jest stałe zainteresowanie autora wypowiedzią dramatyczną, podtrzymywane przez rozległe kontakty ze środowiskiem twórców teatru. Od czasu opublikowanej w 1891 roku chłopskiej tragedii Świat się kończy! Kasprowicz dość regularnie sięgał po formę dramatu, wyczuwając w niej potencjał dla eksterioryzacji nurtujących go problemów natury egzystencjalnej i traktując jako niezastąpione medium w obnażaniu źródeł antropologicznego kryzysu kultury przełomu XIX i XX wieku. Dramaturgia (i całe dzieło) autora Marchołta, wchłonąwszy rozwarstwienie aksjologicznych i metafizycznych koncepcji pokolenia fin de siècle'u, z pełną ostrością oddaje duchowy ferment epoki, uwikłanej w światopoglądowy pesymizm, a zarazem poszukującej skutecznych dróg przezwyciężenia dekadenckiej antropologii, obejmujących z jednej strony buntowniczą negację tradycji, z drugiej zaś dążenia do ustanowienia jej nowego, stabilnego sensu.

Niemal wszystkie znane nam dramaty poety zostały napisane przed rokiem 1908, włączywszy pierwszą część wykluwającego się wówczas z mozołem Marchołta $^{1}$, zamierzonego w kategoriach opus vitae, dokonania o przełomowym znaczeniu i dwubiegunowym zakresie, ogarniającego horyzont przeszłości z antycypacją przyszłych, zaledwie przeczuwanych ścieżek. Całość, opublikowana wiosną 1920 roku, powstawała etapowo w ciągu kilkunastu lat, jak zaświadcza Maria Kasprowiczowa na kartach Dziennika - „z męką, w walce i zmaganiu z samym

* Dr hab., podanna@kul.lublin.pl, Katolicki Uniwersytet Lubelski Jana Pawła II, Instytut Filologii Polskiej, Katedra Dramatu i Teatru, Al. Racławickie 14, 20-950 Lublin.

${ }^{1}$ Przyjmując kolejność według dat ukazywania się drukiem, są to: Świat się kończy! Dramat z życia ludu wielkopolskiego w pięciu odsłonach (Lwów 1891); Na Wzgórzu Śmierci (Lwów 1898); Bunt Napierskiego. Poemat dramatyczny (Lwów 1899); Baśń nocy świętojańskiej. Prolog na otwarcie Teatru Miejskiego we Lwowie (Lwów 1900); Uczta Herodiady. Poemat dramatyczny w trzech aktach. Z cyklu „Na Wzgórzu Śmierci” (Lwów 1905); Narodziny Marchołta. Tragikomedii Marchołta Grubego a Sprośnego część pierwsza, „Chimera” 1907, t. X, z. 30 (grudzień); Sita. Indyjski hymn miłości w trzech odsłonach (sztuka ukończona wiosną 1907 r., druk całości: Poznań 1917). 
sobą"2, wchłaniając życiowe doświadczenia oraz ideowe dylematy twórcy, przeistaczając się $\mathrm{w}$ holistyczną próbę zobrazowania dramatycznych antynomii przypisanych istnieniu człowieka i świata. Kasprowiczowskie „misterium tragikomiczne" zyskało status swoistej syntezy, zarówno jako ostatnie ogniwo twórczości dramatycznej poety, jak i - a może przede wszystkim - odzwierciedlenie meandrów przemian światopoglądowych, jakie zachodziły u niego na przestrzeni bez mała całego życia ${ }^{3}$. „Marchołt to jestem ja sam” - częstokroć powtarzał, wskazując na autobiograficzne proweniencje głównego bohatera ${ }^{4}$.

Zapowiedzi dramatu o tytule Marchołt pojawiają się na progu XX wieku, jednak upłynęło parę lat, zanim doszło do ich urzeczywistnienia w postaci pierwszego obrazu Narodzin Marchołta, który został wydrukowany na łamach „Chimery" w grudniu 1907 roku. Zalążek dzieła krystalizował się więc na drodze artysty od buntowniczych Hymnów, poprzez zbiór poetyckiej prozy $O$ bohaterskim koniu i walacym się domu (1906), ku tomikowi Ballada o stoneczniku i inne nowe poezje (1908), postrzeganemu przez badaczy jako świadectwo stadium przejściowego, ,początek nowej filozofii, która określi ostatni etap twórczości Kasprowicza”. Według relacji Stefana Kołaczkowskiego, poeta „nie miał żadnego pomysłu dalszego ciągu, czuł tylko potrzebę pisania dalej o Marchołcie"'. Można zaryzykować przypuszczenie, że z trudem konsolidował on rozproszone elementy, stopniowo dojrzewając do gotowości kompleksowego przedstawienia życia - jak miał oznajmić - ,we wszystkich jego przejawach, od najsubtelniejszych aż do najbardziej trywialnych i groteskowych”, zamierzonego jako „wielki persyflaż życia"’.

${ }^{2}$ M. Janowa Kasprowiczowa, Dziennik, [cz.] II: Wojna, Wydawnictwo Domu Książki Polskiej, Warszawa 1932, s. 273 (zapis z 6 marca 1916 r.).

${ }^{3}$ Por. M. Sosnowski, Światopoglad Jana Kasprowicza. Elementy i fazy rozwoju, w: Pro memoria. Jan Kasprowicz w osiemdziesiąta rocznicę śmierci, red. M. Sosnowski, G. Igliński, Polskie Bractwo Kawalerów Gutenberga, Warszawa 2006, s. 158.

${ }^{4}$ Postulat uwzględniania Marchołta przez cały czas naukowego obcowania z Kasprowiczem pojawia się już w pierwszych monografiach jego twórczości, jak pisał Zygmunt Wasilewski, ,,inaczej bowiem nie zrozumiemy autora, dlaczego sam w dramacie tym swoje życie widział" (Jan Kasprowicz. Zarys wizerunku, Gebethner i Wolff, Warszawa [1923], s. 98). Por. też J. Kaczyński, Elementy autobiograficzne w ,Marchotcie” Jana Kasprowicza, w: Pro memoria..., s. 353-367.

${ }^{5}$ G. Igliński, Pieśni wieczystej tęsknoty. Liryka Jana Kasprowicza w latach 1906-1926, Wydawnictwo Wyższej Szkoły Pedagogicznej w Olsztynie, Olsztyn 1999, s. 102.

${ }^{6}$ S.K. [S. Kołaczkowski], Posłowie XV tomu, w: J. Kasprowicz, Dzieła, red. S. Kołaczkowski, t. XV, Wydawnictwo Wojciech Meisels, Kraków 1930, s. 288.

${ }^{7}$ M. Janowa Kasprowiczowa, Dziennik, [cz.] I: Moje życie z nim, Wydawnictwo Domu Książki Polskiej, Warszawa 1932, s. 192 (zapis z 26 listopada 1913 r.). Regularnie prowadzony Dziennik poślubionej przez Kasprowicza w 1911 roku Marii Bunin zawiera liczne komentarze poety dotyczące twórczości (oczywiście cytowania mają różny stopień dokładności i początkowo były notowane w przekładzie autorki na język rosyjski). Zapiski na temat Marchołta, zweryfikowane m.in. przez Romana Lotha, zostały uznane za wiarygodne udokumentowanie etapów powstawania dzieła, a także swoiste odzwierciedlenie przebiegu poetyckich zmagań. 
Kontynuacja tego przedsięwzięcia przypadła na ważny okres ewoluowania światopoglądu artysty, który zaczął zdążać do prób akceptacji sprzeczności bytu, przełamywania pesymistycznej filozofii wyrażanej w wizjach dziejowego kataklizmu, rozliczania się z przeszłością i wyznaczania nowego kierunku. „Marchołt jest zamknięciem całego okresu mego dawniejszego życia; nowy jego okres zaczął się w Księdze ubogich" - wprawdzie takie rozgraniczenie jest pewnym uproszczeniem, zważywszy na wyjątkowo złożony proces artystycznych i światopoglądowych przemian poety, jednak stwierdzenie to mocno akcentuje graniczny charakter dzieła ${ }^{8}$. Pełny zrąb dramatu wyłonił się na przełomie lat 1913/1914, w zapamiętałej pasji tworzenia. Tym samym znacząco przesuwa się cezura jego datowania, mimo że planowane od razu wydanie książkowe nie doszło do skutku, a powoli odzyskiwaną przez poetę wewnętrzną równowagę niebawem miały zachwiać wydarzenia pierwszej wojny światowej. Rękopis Marchołta trafił do szuflady, natomiast Kasprowicz wciąż krążył wokół niego myślami, paraliżowany rozterkami, czy w istocie udało mu się stworzyć dzieło o aktualnym i zarazem nieprzemijającym, pozaczasowym przesłaniu, jakie przeczuwał $\mathrm{w}$ trakcie pisania. Tymczasem w codziennym, intymnym obcowaniu z tatrzańską przyrodą zrodziła się poetycka Księga ubogich (1916), gdzie zostały zawarte dalsze akcenty duchowej przemiany, wygaszania ognisk osobistych zmagań, jednania z Bogiem. Równocześnie artysta nie potrafił uporać się z Marchołtem, który wciąż nie dawał mu spokoju, poddawany kolejnym modyfikacjom pod wpływem dylematów i wątpliwości, zwłaszcza w kwestii recepcji czytelniczej utworu w obliczu zmieniającej się sytuacji społeczno-politycznej pierwszych lat budowania polskiej państwowości, a w dalszej perspektywie - w związku ze spodziewaną inscenizacją, której już nie było dane autorowi doczekać. Mocno rozłożony w czasie proces powstawania dzieła, który nie zakończył się wraz z publikacją, absorbując Kasprowicza właściwie do końca życia9 ${ }^{9}$, wskazuje na to, że Marchołt stanowił dlań szczególną próbę ogarnięcia całokształtu egzystencjalnych doświadczeń i przemyśleń, wyrastał z głębokiej potrzeby wydestylowania kwintesencji ludzkiej kondycji.

Świat poetycki Kasprowiczowskich dramatów wytycza rozległy horyzont spraw pierwszych i ostatecznych, włączając konkretną, osadzoną „tu i teraz” historię w uniwersalną skalę „wszędzie i zawsze”, „gdziekolwiek i kiedykolwiek”. Wielopłaszczyznowa problematyka Marchołta została podporządkowana dramatycznej konwencji o cechach misteryjnych i moralitetowych (ze zdecydowaną przewagą tych ostatnich), z typowym dla epoki przełomu XIX i XX wieku synkretycznym traktowaniem gatunków średniowiecznego teatru religijnego,

${ }^{8}$ Tamże, [cz.] II: Wojna, s. 287 (zapis z 16 lipca 1916 r.).

${ }^{9}$ Poeta w ostatnich miesiącach przed śmiercią (zm. 1 sierpnia 1926 r.) po raz kolejny powrócił do idei udoskonalenia dramatu, z pomocą żony nanosząc poprawki do ewentualnego drugiego wydania, w sferze planów znajdowała się też realizacja sceniczna. 
kontynuowanym przez twórców dwudziestolecia międzywojennego. Pojęcia te stosowano zwykle wymiennie, w różnych kontekstach i znaczeniach, poszukując dramatu i teatru zgłębiającego tajniki duszy człowieka, ukazującego metafizyczne aspekty istnienia ${ }^{10}$.

Dzieje tytułowego bohatera „misterium tragikomicznego" Kasprowicza obrazują węzłowe fazy człowieczej peregrinatio vitae, od momentu narodzin aż do śmierci, oscylującej pomiędzy duchowością a cielesnością, marzeniem a prawami rzeczywistości, nadzieją a rezygnacją, triumfem a upadkiem; sygnowanej duchową szamotaniną i egzystencjalnym lękiem, pragnieniem dobra i zanurzeniem w grzechu, bezustanną walką z własną przyrodzoną naturą. „Żywot słaby - / wszystko idzie z trwogą..."11 - wyrokuje Żebrak, który zjawia się w chłopskiej izbie jako pierwszy z gości świętujących Marchołtowe przyjście na świat i który potem, ujawniając oblicze antycznego Fauna-Pana, będzie mu asystował w newralgicznych momentach życiowych aż do śmierci, uświadamiając kolizję między wyżynami ducha a spychającą w dół słabością ciała, podsycając uczucie lęku nieodłącznie stygmatyzującego ziemską egzystencję. W drugim obrazie Marchołt, rozpocząwszy drogę inicjacji w wiek męski, usłyszy od Żebraka-Fauna-Pana:

Śmieszne twoje panowanie!

Gdzie postawisz stopę, w bucie

czy też bosą, trwogi kłucie

będziesz miał po wieków wiek,

boś jest tylko marny człek!... ${ }^{12}$

Jednakże pierwszym doświadczeniem nowo narodzonego jest utrata matki, co symbolicznie ujmuje odwieczną kolej bytu w przemienności rotującego koła, a przy tym prowokuje filozoficzne zapytania o niepojętą ludzkim umysłem logikę świata:

Panie Boże! Panie Boże!... hę?

życie ludzkie w takiej cenie?

${ }^{10}$ Por. A. Truskolaska, Młodopolska ekspansja pojęcia „,misterium”, w: Wśród mitów teatralnych Młodej Polski, red. I. Sławińska, M.B. Stykowa, Wydawnictwo Literackie, Kraków-Wrocław 1983, s. 277-308; E. Rzewuska, Misterium i moralitet w polskim dramacie międzywojennym, w: Dramat i teatr religijny w Polsce, red. I. Sławińska, W. Kaczmarek, Towarzystwo Naukowe KUL, Lublin 1991, s. 287-328.

${ }^{11} \mathrm{~J}$. Kasprowicz, Marchołt gruby a sprośny. Jego narodzin, życia i śmierci misterium tragikomiczne w obrazach czterech zamknięte, w: tenże, Pisma zebrane, wyd. krytyczne pod red. J.J. Lipskiego i R. Lotha, t. VI: Utwory literackie 6, Wydawnictwo Literackie, Kraków 2002, s. 11.

12 Tamże, s. 98. 
$[\ldots]$

co ważniejsze, śmierć czy życie?

I czy taki Marchołt gruby

wart matczynej zguby? ${ }^{13}$

W „misterium tragikomicznym narodzin, życia i śmierci” Marchołta, czyli Każdego, jest to fundamentalny dylemat, osobliwie wybrzmiewający w rubasznej tonacji dialogów pierwszej odsłony, gdzie śmiech graniczy ze smutkiem, a obrzędy związane $\mathrm{z}$ urodzinami ( $\mathrm{w}$ tradycji kujawskiej zwane popielinami) niespostrzeżenie stapiają się z czasem żałoby. Wszechobecność śmierci towarzyszy poecie na każdym kroku, w myśl średniowiecznej ars moriendi, nakazującej oswajanie się z nieuchronnym kresem ${ }^{14}$. W jednym $\mathrm{z}$ wczesnych utworów poetyckich Kasprowicz stwierdza, ,[...] że co ginie, nie ginie daremnie”, a „,[...] świat do życia zawsze przez śmierć będzie kroczył..." ${ }^{15}$. Ustawiczne obcowanie z myślą o zmienności i trwaniu zostało zobrazowane w Marchołcie poprzez przełamywanie radosnej sceny narodzin rozlicznymi znakami uprzytomniającymi znikomość i przygodność egzystencji. To pewien paradoks niekoniecznie wynikający z samych założeń twórczych, ale także z chłopskiego obyczaju i mentalności, w której w naturalny, odwieczny sposób trwają obok siebie początek i koniec, jak dzień obok nocy ${ }^{16}$. Wyraźnie przy tym zaznacza się współistnienie dwóch oddziałujących na siebie światów - realnego i irracjonalnego. Marchołtową kołyskę otaczają widma Aniołów-Kolędników, przybyłych jako zwiastuni sakralnego czasu Chrystusowego Narodzenia, którzy wnet ustępują orszakowi Braci

${ }^{13}$ Tamże, s. 30, 59.

${ }^{14}$ Por. J. Tuczyński, Kasprowicz. Pogłos wieczności, Oficyna Wydawnicza „Nirwana”, Bydgoszcz 1996, s. 184-188.

15 J. Kasprowicz, Z przyjściem jesieni, w: tenże, Pisma zebrane, wyd. krytyczne pod red. J.J. Lipskiego i R. Lotha, t. I: Utwory literackie I, oprac. R. Loth, Wydawnictwo Literackie, Kraków 1973, s. 52, 54. Jest to utwór z cyklu Melodie jesienne, zamieszczony w pierwszym tomiku Poezji (Lwów 1888). Warto przywołać jeszcze jeden jego fragment, który ilustruje antynomiczne widzenie świata:

Rzeczywistości, i ty, złudna maro!

Harmonio dźwięków! dysonansów zgrzycie!

Bezdenna próżnio! przepełniona czaro!

Przed tobą w niemym upadnę zachwycie,

Bo wiem, że ty się składasz w wieczne Jedno - w Życie... (s. 52)

${ }^{16}$ Przypomnijmy, że dynamikę ewolucji Kasprowicza w sferze przeżyć duchowych i światopoglądowych kształtowało wiele czynników, wśród których fundamentalne miejsce zajmowało jego organiczne zakorzenienie w źródłach rodzimej tradycji. „Ludowość Kasprowicza objawia się wtedy, gdy objawia się w całej pełni jego indywidualność, gdy dzieje się bez jego woli i zamierzeń, wtedy może właśnie, gdy nic nie mówi o ludzie, o nim nie myśli” - stwierdzał Stefan Kołaczkowski (Wyspiański. Kasprowicz. Przeglady, oprac. S. Pigoń, Państwowy Instytut Wydawniczy, Kraków 1968, s. 237). Por. też M. Sosnowski, Jan Kasprowicz. Opowieść biograficzna, cz. 1: Chłopska sukmana (1860-1889), Stowarzyszenie Przyjaciół Twórczości Jana Kasprowicza, Zakopane 2015. 
Pogrzebowych. „Jak to zawsze / jedno drugie goni: / śmierć i życie” - puentuje jeden $\mathrm{z}$ bohaterów ${ }^{17}$. Wysłannicy śmierci powrócą $\mathrm{w}$ finalnym obrazie dramatu, swoistą klamrą spinając ludzkie przeznaczenie, sprzężone $\mathrm{z}$ wizją śmiertelnika wpisanego w deterministyczną antropologię: „kroczym, gdzie Dola nas woła... / [...] nie czynim złego nikomu, / spełniamy losy człowiecze!..."18. Wiedzę tę wydają się posiadać świadkowie Marchołtowych narodzin, którzy z niezachwianą pogodą ducha uznają konieczność życiowych antynomii, w naturalny sposób przyjmując wartość życia i konieczność śmierci:

Ino po co nam o śmierci

zagadywać. Przyjdzie sama

i do pana, i do chama

w samą porę ${ }^{19}$.

I nieco dalej:

Życie ludzkie jest jak dech:

Pan Bóg dmie w organny miech,

a jak ino dąć przestanie $---^{20}$

Śmierć jako kres wszystkiego czy raczej przejście w inny wymiar istnienia? - to jedna z newralgicznych kwestii egzystencjalnych obecnych w twórczości Kasprowicza. Doświadczenie narodzin i zgonu, a także od początku zapowiedzianego w Marchołcie grzechu i krzyża, nie oznacza już całkowitego zatrzaśnięcia człowieka w przestrzeni mortalizmu - jak w poprzednich dramatach poety - ale implikuje dalsze ogniwo istnienia, czyli nie uwzględnianą wcześniej chrześcijańską perspektywę soteriologiczną. O ile w debiutanckiej tragedii Świat się koń$c z y$ ! nie przekonuje machinalna próba podtrzymywania resztek nadziei: „Juści to, powiadają, śmierć jest ino przejściem do lepszégo życiá...”21, to w ostatnim dramacie Kasprowicza postawa chłopskich bohaterów emanuje niespodziewaną pewnością: „Wiemy o tym wyśmienicie, / czym jest życie!...”, „Niebem, piekłem - / jak dla kogo..."22. Życie ludzkie wskazuje nie tylko na horyzontalizm doczesnych aspiracji, ale także na wertykalizm, odnoszący się do przywracania zagu-

${ }^{17}$ J. Kasprowicz, Marchott..., s. 58.

18 Tamże, s. 279.

19 Tamże, s. 14.

20 Tamże, s. 20, por. 25.

${ }^{21}$ J. Kasprowicz, Świat się kończy! Dramat z życia ludu wielkopolskiego w pięciu odstonach, w: tenże, Pisma zebrane, wyd. krytyczne pod red. J.J. Lipskiego i R. Lotha, t. II: Utwory literackie 2, oprac. R. Loth, Wydawnictwo Literackie, Kraków 1974, s. 167.

22 J. Kasprowicz, Marchott..., s. 25. 
bionej relacji z Bogiem. O istnieniu nieba, skonkretyzowanego w duchu ludowej filozofii, zaświadczą ci, którzy oczekiwali Marchołtowego przyjścia na świat i w czwartym obrazie przybywają z zaświatów w celu oswojenia go ze sprawami ostatecznymi, które literatura modernizmu przeważnie omijała, mnożąc za to wizje totalnej katastrofy i unicestwienia bytu, wpisując w apokaliptyczny entourage dylematy egzystencjalne, metafizyczne i moralne epoki. Niemal wszyscy młodopolscy pisarze, na czele z Kasprowiczem, reagowali na religijne rozterki człowieka podejmując motyw dies irae - Sądu Ostatecznego (nie oznaczał on jednak nastania po nim Królestwa Bożego) czy końca świata proklamowanego przez Apokalipsę $e^{23}$.

Przypomnijmy, że dramatis personae chłopskiej tragedii Kasprowicza trwały w eschatologicznym potrzasku „końca świata”, doświadczając paraliżującej niemocy w zderzeniu z fundamentalnymi pytaniami o sens, zmagając się z głębokim poczuciem braku sprawiedliwości (w wymiarze społecznym i etycznym). Dusza Wygnana z Raju w biblijnej dylogii Na Wzgórzu Śmierci i Uczta Herodiady, zniewolona afektywną relacją z Lucyferem, kierowała ku odległemu Stwórcy serię oskarżeń: „Gdzież jest zbawienie?...”, „Memu istnieniu czemuż nie ma końca?! / Zanim mnie z Raju wygnano, dlaczego / Ta Moc Najwyższa nie kazała zginąć / I mnie, i złemu, które było we mnie / I które stało się nasieniem złego?!”24, „Czemuś mnie stworzył?!!!...””25. Ten swoisty Kasprowiczowski teatr śmierci (w różnych jej przejawach, związanych z lękiem, cierpieniem, próżnią itp.) utrwalał obraz Golgoty z gasnącym cicho na krzyżu Zbawicielem. Rozpaczliwy Głos z Krzyża: „Boże! mój Boże! czemuś mnie opuścił?!"26, wybrzmiewający poza kontekstem Nowego Testamentu, stwierdzał obojętność Boga wobec dokonującej się zbrodni, pieczętował dziejową klęskę chrześcijaństwa, definitywnie skazującą ludzkość na trwanie w wiecznej agonii bez nadziei zbawienia. Trudno o bardziej przenikliwe obnażenie aksjologicznej próżni, jaka wyłania się na skutek konsekwentnej dekonstrukcji pierwotnej logiki biblijnej antropologii, intensyfikującej optykę metafizycznego i egzystencjalnego katastrofizmu.

${ }^{23}$ Piszą na ten temat m.in.: W. Kaczmarek, Złamane pieczęcie Księgi. Inspiracje biblijne w dramaturgii Młodej Polski, Redakcja Wydawnictw KUL, Lublin 1999; W. Gutowski, Pokusy nicości i tajemnice Pelni. Młodopolskie obrazy eschatologii, w: tenże, Z próżni nieba ku religii życia. Motywy chrześcijańskie w literaturze Młodej Polski, Wydawnictwo Literackie, Kraków 2001, s. 316-369.

${ }^{24}$ J. Kasprowicz, Na Wzgórzu Śmierci. Poemat dramatyczny, w: tenże, Pisma zebrane, wyd. krytyczne pod red. J.J. Lipskiego i R. Lotha, t. III: Utwory literackie 3, cz. 2, oprac. R. Loth, Wydawnictwo Literackie, Kraków 1997, s. 180, 196.

25 J. Kasprowicz, Uczta Herodiady. Poemat dramatyczny w trzech aktach. Z cyklu „Na Wzgórzu Śmierci”, w: tenże, Pisma zebrane, wyd. krytyczne pod red. J.J. Lipskiego i R. Lotha, t. IV: Utwory literackie 4, oprac. R. Loth, Wydawnictwo Literackie, Kraków 1984, s. 355.

${ }^{26}$ J. Kasprowicz, Na Wzgórzu Śmierci, s. 201. 
Marcholt, choć odległy jeszcze od afirmatywnej filozofii życia - stopniowo uwidaczniającej się w lirykach składających się na Księgę ubogich (1916) i Mój świat (1926) - sygnalizuje kierunek przekraczania pesymistyczno-dekadenckiej antropologii, kontrapunktując wizję człowieka znajdującego się w niewoli cierpienia i lęku, duchowej samotności i pustki. Poeta, na nowo odsłaniając zagadkę istnienia, nie rozwiązuje antynomii przynależnych ludzkiej kondycji. Znamienną sygnaturą jego percepcji rzeczywistości jest bezsilność wobec metafizycznej obecności dobra i zła oraz triumfu śmierci nad życiem. Bohaterowie Marchołta nieustannie więc stają $\mathrm{w}$ obliczu spraw znajdujących się poza zasięgiem ich poznawczych możliwości, funkcjonując w naznaczonej defektem rzeczywistości, gdzie ,czart to ludzkie plemię / ciągle kusi...”, „człek się musi / wciąż oganiać... ciągłe bitwy / z złem"27, a „stojący na uboczu” Bóg ,ino się podśmiechuje"28. Zważywszy na średniowieczno-renesansowy rodowód gatunkowo-stylistyczny dramatu, w filozofii życia prezentowanej przez uczestników popielin aż nazbyt czytelnie wybrzmiewają frazy Jana Kochanowskiego: „Sam Bóg wie przyszłe rzeczy, a śmieje się z nieba, / Kiedy się człowiek troszcze więcej niźli trzeba" (Pieśń IX).

Skumulowane w świecie zło i grzech - choć są nienaruszalnym i niezrozumiałym faktem - nie niweczą już Bożego planu odkupienia, w wygłosie utworu mieści się bowiem pozytywna eschatologia, objawiona w zbawczej nadziei dla człowieka zawładniętego przez kult cielesności i chuci, co z dużą dozą teatralnej ekspresji wybrzmiało między innymi w obrazie świętowania narodzin Marchołta, wiodącego do pogrążenia się biesiadników w ferworze żywiołowej zabawy sfinalizowanej w widowiskowym tańcu o podłożu dionizyjskim. Scena ta ma zarazem podskórny wydźwięk, wskazujący na potrzebę zagłuszania trosk doczesności: „Niech sobie pohula, / będzie mu wyraźniej / bez lęku, bojaźni”, "dajcie wódki / na otuchę", „choć jest smutek, jest wesele”29. Wydaje się to nęcącą alternatywą w obliczu narastającego w sytuacji granicznej metafizycznego niepokoju związanego ze świadomością, że „czas jest krótki”, na progu życia czai się śmierć, tragizm egzystencji ociera się o komizm. Humor Marchołta daleki jest od beztroskiej, niefrasobliwej pogody, wymaga ostrożności i czujnego skupienia. Poeta płynnie gra kontrastami, intensyfikuje wewnętrzne napięcia i dysonanse, nie stroni od plebejskiej błazenady, satyry i groteski, obnażając absurdalność świata, wzbudzając śmiech podszyty przerażeniem ${ }^{30}$.

27 Tenże, Marcholt..., s. 41.

${ }^{28}$ Tamże, s. 33.

29 Tamże, s. 32-33, 59.

${ }^{30}$ Stylistyczne konwencje dramatu w dużej mierze wyznacza rodowód tytułowego bohatera, wywiedziony z ludowych opowieści o dziejach mędrkującego chłopa (Rozmowy, które miat król Salomon mądry z Marchottem grubym a sprośnym Jana z Koszyczek), a także nawiązujący do motywu ,z chłopa król”, w Polsce spopularyzowanego m.in. przez komedię Piotra Baryki. W pierwodruku obrazu Narodzin Marchołta w „Chimerze” poeta zasugerował też trop sowizdrzalski, wprowadziwszy zwrot do odbiorcy zaczerpnięty z prologu do Komedii rybałtowskiej nowej. 
Człowiecze istnienie kształtuje się w napięciu życie - śmierć, duchowość cielesność, czemu równolegle towarzyszy nieustannie drążony przez Kasprowicza problem ambiwalentnej natury miłości, rozdartej pomiędzy ideałem transcendentnego uczucia a wszechwładzą żądzy zmysłowej, między miłością-ukojeniem i błogosławieństwem a destruktywną miłością-grzechem. W tym kierunku przesuwają się akcenty drugiego obrazu dramatu, zatytułowanego Las-Kościól czyli dzieje miłości i zaślubin Marchołtowych. Należy przy tym pamiętać o szczególnej, organicznej wrażliwości poety na świat przyrody, w intymnym obcowaniu z którą doświadcza on istnienia wyższych mocy, odkrywa ślady transcendencji, w rezultacie - jak pisał Konrad Górski - „las zawsze kojarzy [mu] się z kościołem”31. Horyzontalny układ zdarzeniowy nieprzerwanie krzyżuje się z wertykalnym porządkiem rzeczywistości pozaziemskiej, uobecnianej w różnorakich kontekstach „misterium tragikomicznego". Poddawana sakralizacji przestrzeń natury, będąca scenerią miłosnej inicjacji bohatera, skrywa zarazem pierwiastki demoniczne, promieniuje splatającą się z duchowością siłą zmysłowości, wyzwalając strumień pierwotnych instynktów. Wkraczamy zatem w krąg typowo modernistycznej metafizyki miłości, uwikłanej w pożądliwość, grzeszność, cierpienie, która wchłonęła mizoginistyczne klisze epoki wraz z reperkusjami osobistych tragedii poety. Nie jest dziełem przypadku, że Marchołt-idealista oswaja się ze światem materialnym pod naporem zespolonej aktywności Fauna-Pana, kumulującego wszystko to, co w Marchołtowym świecie ,grube a sprośne”, oraz „niewieściego tworu” reprezentowanego przez Królewnę. Jak zauważa Grzegorz Igliński we wnikliwej analizie symboliki postaci Fauna, jest on źródłem wszystkich napięć i antynomii uobecniających się w dramacie. „Faun to coś, co Marchołta przerasta, dominuje nad nim, kieruje jego krokami - ukazuje się jako postać tego, co człowiek sam w sobie przeżywa jako przewyższającą go moc"32. Marchołtowe „zakorzenienie" w bycie utrwala poprzez relację z kobietą, która ostatecznie pociąga go za sobą w głąb lasu, pętając biologicznymi prawami życia, rozbudza drzemiącą potęgę pożądliwości, tłumiąc sferę duchowych pragnień.

W kreacji Marchołta już od momentu przyjścia na świat zaznacza się nieprzystawalność wielkości ducha do przyziemnych potrzeb i tymczasowości płaszczyzny cielesnej. Narodziny bohatera otacza nieuchwytna aura transcendencji, $\mathrm{w}$ dużej mierze wypływająca $\mathrm{z}$ paralelnego włączenia jego biografii w matrycę losów Chrystusa ${ }^{33}$, stąd też swoistym dysonansem jest sposób opisywania

\footnotetext{
${ }^{31}$ K. Górski, Religijność Kasprowicza, w: Religijne tradycje literatury polskiej. 1. Polska liryka religijna, red. S. Sawicki, P. Nowaczyński, Wydawnictwo Towarzystwa Naukowego KUL, Lublin 1983, s. 345. Por. też W. Gutowski, Tajemnice młodopolskich lasów. O kluczowym symbolu poetyckim, w: tenże, Mit -Eros - Sacrum. Sytuacje młodopolskie, Wydawnictwo Homini, Bydgoszcz 1999, s. 97-112.

${ }^{32}$ G. Igliński, dz. cyt., s. 216-217.

${ }^{33}$ Zob. J. Kasprowicz, Na marginesie „,Marchotta” [sonet III], w: tenże, Pisma zebrane, t. VI: Utwory literackie 6, dz. cyt., s. 513.
} 
niemowlęcia zrodzonego dla „wielkiej chwały”, ale obdarzonego krzepką aparycją „wielce sprośnego młodziana”. Tutaj zaznacza się kolejny rys ewolucji Kasprowiczowskiego światopoglądu. Kult człowieka „niepospolitego”, „wielkiego”, „wyższego" był - jak dobrze wiadomo - niezwykle trwale zakorzeniony $\mathrm{w}$ antropologii epoki modernizmu. Towarzyszyło mu przeświadczenie, że ludzie wielcy powstrzymują napór ludzi pospolitych, miernych, rozbitych, gnuśnych, a przy tym scalają i pogłębiają nie tylko życie zewnętrzne, ale również duchowe. Idea „wielkości” w ówczesnej wyobraźni była blisko spokrewniona z projekcją „człowieka twórczego”, „tworzącego”, który kształtuje samego siebie i otoczenie, a zarazem przekracza to, co już zostało zbudowane, poszerzając przestrzeń istniejącego porządku ${ }^{34}$. W tym kontekście należałoby umieścić Marchołtową (czyli Kasprowiczowską) postawę buntu wobec wszelkiej małości i pokus konformizmu, ściśle zespoloną z bliską poecie ideą prometejską ${ }^{35}$.

Dzieje bohatera zostały biegunowo rozpostarte pomiędzy spektakularną karierą, nawiązującą do znanego literackiego schematu „z chłopa król”, a doszczętnym zdruzgotaniem wyznawanych ideałów. W trzecim, rozpadającym się na kilka wątków obrazie „tryumfu i upadku Marchołta” poeta usiłował pomieścić rozległe spektrum problematyki społeczno-politycznej (w jej aktualnych i uniwersalnych przejawach), diagnozując kryzys świata zanurzonego w aksjologicznym chaosie, pogrążonego w stanie kulturowej erozji. W ekspresjonistycznej wizji upadku cywilizacji pojawiają się zarazem akcenty odrodzeńcze, przełamujące typowe dla nurtu pesymistyczno-dekadenckiego poczucie impasu. Kasprowicz podnosi moralną wartość jednostek, które są zaczynem rewolucji, „,co mają w sobie fermenty, / rozsadzające światy!"36, zapamiętale budząc pogardę dla gnuśności tłumu proklamowaniem postawy heroicznego nonkonformizmu rodem z Ibsenowskiego Branda: „wszystko albo nic!”37. Jak spostrzegała między innymi Maria Podraza-Kwiatkowska, katastroficzna wyobraźnia i towarzyszące jej wizje burzenia martwej formy należą nie tylko do nurtu dekadenckiego, ale mogą być też elementem postawy aktywnej, kreacyjnej, powiązanej z postulatem odnowy

${ }^{34}$ Zob. M. Stala, Człowiek z właściwościami. (W kręgu antropologicznej problematyki Młodej Polski), w: Stulecie Młodej Polski, studia pod red. M. Podrazy-Kwiatkowskiej, Universitas, Kraków 1995, s. 146-149.

${ }^{35}$ Poeta cenił postawę prometejską, obejmującą element negatywny (bunt przeciw temu, co ogranicza szczęście) i pozytywny (gotowość do poświęcenia, miłość). Na uwagę zasługuje także wyraźna na różnych etapach twórczości Kasprowicza (również w Marchołcie) paralelność postaci Chrystusa i Prometeusza, dość powszechna w interpretacjach modernistów.

36 J. Kasprowicz, Marcholt..., s. 275.

37 Wskazana paralela nie jest przypadkowa - dramat Ibsena, przetłumaczony przez Kasprowicza pod koniec 1911 roku, stanowi istotny kontekst dla ideowego dojrzewania Marchołta. Pisała na ten temat m.in. A. Grzybiakówna w artykule Kasprowicz i Ibsen, „Rocznik Kasprowiczowski” III (1982), s. 107-112. 
moralnej, doskonalenia się, wewnętrznego heroizmu ${ }^{38}$. Na progu XX wieku katastroficzne fascynacje zaczynają ustępować miejsca odrodzeńczemu światopoglądowi, często wyrażanemu za pomocą leksykalnego arsenału o proweniencjach militarnych. W ten nurt wpisuje się obecna w Marchotcie metaforyka wojenna, występująca w kontekście znamiennego dla epoki obrazowania agrarnego i służąca heroizmowi w sferze wartości duchowych. Stąd na przykład mowa o potrzebie przeorywania zachwaszczonej czy zatwardziałej gleby duszy i wzbudzania „plonnych posiewów”, a symbolika krwawej wichury, płomienistej powodzi i popieliska sprzężona jest z oczekiwaniami, że się ,[...] jakiś nowy świat narodzi / dla człowieka, który będzie / pewny siebie, / pewny świata / już na wieczne dni i lata!"39. Młodopolskie wzorce niszczenia starych, przeżytych form i budowania nowych mają silne zakorzenienie w romantyzmie. Do tej tradycji włączają się inspiracje Nietzscheańskie, które pobudzały wyobraźnię modernistów nie tylko w sferze światopoglądu, ale także metaforyki. „Trzęsienie ziemi nowe źródła objawia" ${ }^{\prime 40}$ - ten sposób ekspresji będzie też bardzo charakterystyczny dla bohatera Kasprowiczowskiego „misterium tragikomicznego”. Destrukcja jest koniecznym elementem nowej kreacji, tylko wskutek rozsadzenia skarlałego świata może wyłonić się nowa budowla. Zgruchotana wielkość Marchołta-króla rozwiewa zarazem wszelkie złudzenia co do wyższej świadomości „ludzkiego motłochu”, prozaicznie złaknionego „ducha, chleba i rozrywki”"11. Bezwzględny radykalizm i pycha bohatera, brak zgody na istniejący status quo i nonkonformizm, wreszcie „,nieludzkie plany”, polegające na budowaniu nowej rzeczywistości opartej wyłącznie na fundamentach duchowych, z wyeliminowaniem praw ciała, pogłębiają jego wewnętrzne pęknięcie oraz przepaść między nim a światem.

Toczona przez Marchołta walka z własnym losem, z życiem i wpisanymi w nie sprzecznościami, jest zarazem częścią nieustającego wadzenia się z Bogiem, będącym usilnie, aczkolwiek bezskutecznie przywoływanym interlokutorem w próbach wydarcia odpowiedzi na wątpliwości i pytania natury

${ }^{38}$ M. Podraza-Kwiatkowska, Młodopolska wyobraźnia katastroficzna. Zarys problematyki, w: taż, Wolność i transcendencja. Studia i eseje o Młodej Polsce, Wydawnictwo Literackie, Kraków 2001, s. 66. Autorka zauważa, że taka postawa wyraźnie zaznacza się w literaturze powstałej pomiędzy rewolucją 1905 roku a wybuchem pierwszej wojny światowej, a zatem Marcholt chronologicznie mieści się w tym okresie.

39 J. Kasprowicz, Marcholt..., s. 216.

${ }^{40}$ F. Nietzsche, Niewczesne rozważania, przeł. L. Staff, nakł. Jakóba Mortkowicza, WarszawaKraków 1912, s. 155.

${ }^{41}$ Tamże, s. 130. Zdaniem Jana Kaczyńskiego, światopoglądowe przemiany poety mogą wskazywać na to, że miał on już za sobą lekturę takich studiów, jak Psychologia tłumu Gustave’a Le Bona (pierwsze wyd. francuskie 1897, tłumaczenie polskie 1899) czy Echa prawieku Jana Karola Kochanowskiego (Warszawa 1910). Zob. J. Kaczyński, dz. cyt., s. 362-363. „Być może, wystąpienie na widownię tłumów, będzie jedną z ostatnich faz cywilizacji Zachodu" - pisał Le Bon, równocześnie dostrzegając w tej ,pierwotnej anarchii” stan poprzedzający „kiełkowanie nowych form społecznych" (Psychologia tlumu, przeł. B. Kaprocki, wyd. 3 popr., PWN, Warszawa 1986, s. 43). 
epistemologicznej (zob. zwłaszcza obraz czwarty Walka Jakuba z Aniołem czyli śmierć Marchołta). Modernistyczne załamanie wiary w prawdy chrześcijańskiej teologii jawi się jako doświadczenie odległe od optymistycznej pewności racjonalistycznego ateizmu, przeżycie kryzysu religijnego i światopoglądowego staje się źródłem głębokiego pesymizmu. Konrad Górski interpretuje filozoficzne przesłanie dramatu Kasprowicza jako ,[...] samotne zmaganie się jednostki o wielkich zamiarach zarówno z pospolitym światem, jak i z demonicznymi potęgami, których nadprzyrodzonej istoty i roli w strukturze wszechświata człowiek nie może przeniknąć. Człowiek ten jest pozostawiony wyłącznie własnym siłom i niebo nie spieszy mu z żadną pomocą" ${ }^{\text {"2 }}$. Niebo w Marchołcie nie jest puste, jednakże relacja człowieka i Boga naznaczona jest pewnego rodzaju dystansem, nieufnością. Przypomnijmy, że „stojący na uboczu” Stwórca „wszystko przenika [...] i wszystko czuje"43, ale nigdy nie objawia się w pełni, zawsze występując $\mathrm{w}$ formie pewnych intuicji.

Beznadziejność człowieczych zmagań z Losem, jaką obrazuje „misterium tragikomiczne" o Marchołcie, wzmaga niezaspokojoną tęsknotę za stanem duchowego balansu, wyciszenia wewnętrznych walk. Czy jest on możliwy po spustoszeniu, jakie dokonało się za sprawą antropologicznego kryzysu przełomu XIX i XX wieku? Wszak podstawowym doświadczeniem kultury modernizmu stała się dezintegracja otaczającej rzeczywistości i zagubienie w świecie relatywnych wartości. Ostatni dramat Kasprowicza nie daje pełnej odpowiedzi na egzystencjalne dylematy, za to odsłania istnienie drogi chrześcijańskiego ładu. I chociaż Marchołt jest wielkim przegranym, pokonanym przez potężniejsze od niego siły, w jego porażce u kresu życia w postawie rezygnacji przebłyskują zarodki nadziei:

[...] O, czemu

Bronisz się jeszcze, by z tego Eremu,

$\mathrm{Z}$ tego wygnania nie uciec co prędzej?

Czekaj, za chwilę sam On ci pomoże,

Byś stał się - Sobą. Spokojem, ty wzorze

Człeczych szamotań i człowieczej nędzy!...44

Newralgicznym momentem obrazu Marchołtowej śmierci jest walka, alegorycznie nawiązująca do starcia biblijnego Jakuba z Aniołem, która stanowi krańcową próbę rozwikłania zagadki ludzkiego bytowania. Ostatecznie śmierć jest dla

${ }^{42}$ K. Górski, ,,Marcholt”, w: tenże, Jan Kasprowicz. Studia, Państwowy Instytut Wydawniczy, Warszawa 1977, s. 81-82.

43 J. Kasprowicz, Marcholt..., s. 33.

${ }^{44}$ J. Kasprowicz, Na marginesie „Marcholta” [sonet XI], dz. cyt., s. 521. 
niego wyzwoleniem, jak zauważa Grzegorz Igliński, ,przywraca utraconą jedność i spokój”, dzięki niej „,pryska złudzenie biegunowości istnienia, rozdarcie zostaje uleczone”; ,śmierć «godzi» ducha i ciało”, „napięcie spada, trwoga życiowa zni$\mathrm{ka}^{\text {"45 }}$. Poczucie wewnętrznego rozdarcia człowieka ujawnia w twórczości Kasprowicza różne oblicza, na co wskazują również sugestie interpretacyjne badacza, sytuujące wcześniejszy dramat $\mathrm{Na}$ Wzgórzu Śmierci w rozległym kontekście pojęć filozoficzno-religijnych, określony jako poemat o „świadomości nieszczęśliwej”, bo rozdwojonej ${ }^{46}$. Marcholt zaś ostatecznie potwierdza, że Kasprowicz do końca zmaga się z tajemnicą istnienia człowieka, jego powołania i drogi od narodzin do śmierci, stworzenia ku dobru i zanurzenia w grzechu, rozpięcia między „górą" i „dołem”, duchowością i cielesnością, idealistycznymi pragnieniami a pożądliwością, potrzebą wolności i zniewolenia w iluzjach szczęścia oferowanych przez cywilizację hedonizmu. Nie zdążył on w pełni zrealizować swych dramatyczno-teatralnych ambicji, w Marchołcie zatrzymawszy się jakby w pół drogi, pomału dojrzewając do syntezy egzystencjalnych doświadczeń, przełamywania pesymistycznej filozofii, wzbudzenia postawy pokory i ufności wobec Opatrzności. Prawdziwe pogodzenie dokona się dopiero w poetyckiej Księdze ubogich, znajdując dopełnienie w Moim świecie. Od modelu Marchołta, kurczowo trzymającego się racjonalizmu współczesnej cywilizacji, nie potrafiącego zaakceptować swej skończoności, poeta przechodzi do afirmacji życia współbrzmiącego z naturą, pojednania z samym sobą i Bogiem, odnalezienia upragnionej harmonii wszechświata ${ }^{47}$.

\section{Bibliografia}

Górski Konrad, Jan Kasprowicz. Studia, Państwowy Insytut Wydawniczy, Warszawa 1977.

Górski Konrad, Religijność Kasprowicza, w: Religijne tradycje literatury polskiej. 1. Polska liryka religijna, red. S. Sawicki, P. Nowaczyński, Wydawnictwo Towarzystwa Naukowego KUL, Lublin 1983, s. 341-369.

Grzybiakówna Alicja, Kasprowicz i Ibsen, „Rocznik Kasprowiczowski” III (1982), s. 107-112.

Gutowski Wojciech, Mit-Eros - Sacrum. Sytuacje młodopolskie, Wydawnictwo Homini, Bydgoszcz 1999.

Gutowski Wojciech, Z próżni nieba ku religii życia. Motywy chrześcijańskie w literaturze Młodej Polski, Wydawnictwo Literackie, Kraków 2001.

Igliński Grzegorz, Pieśni wieczystej tęsknoty. Liryka Jana Kasprowicza w latach 1906-1926, Wydawnictwo Wyższej Szkoły Pedagogicznej w Olsztynie, Olsztyn 1999.

\footnotetext{
${ }^{45}$ G. Igliński, dz. cyt., s. 195.

${ }^{46}$ Zob. G. Igliński, ,Homo religiosus” i paradoksy egzystencji, w: tenże, Śmiałość Erosa i świętość Krzyża. Egzystencjalna teodycea „Na Wzgórzu Śmierci” wobec tradycji antycznej i judeochrześcijańskiej, Wydawnictwo Wyższej Szkoły Pedagogicznej w Olsztynie, Olsztyn 1995, s. 155-170.

${ }^{47}$ Studium dotyczy tylko wybranych aspektów problematyki Marchołta. Szerszą propozycję interpretacji dramatu przedstawiam w monografii Świat, który się nie kończy. Człowiek i transcendencja w teatrze Jana Kasprowicza (Wydawnictwo KUL, Lublin 2014).
} 
Igliński Grzegorz, Śmiałość Erosa i świętość Krzyża. Egzystencjalna teodycea „Na Wzgórzu Śmierci” wobec tradycji antycznej i judeochrześcijańskiej, Wydawnictwo Wyższej Szkoły Pedagogicznej w Olsztynie, Olsztyn 1995.

Kaczmarek Wojciech, Złamane pieczęcie Księgi. Inspiracje biblijne w dramaturgii Młodej Polski, Redakcja Wydawnictw KUL, Lublin 1999.

Kaczyński Jan, Elementy autobiograficzne w „Marchołcie” Jana Kasprowicza, w: Pro memoria. Jan Kasprowicz w osiemdziesiąta rocznicę śmierci, red. M. Sosnowski, G. Igliński, Polskie Bractwo Kawalerów Gutenberga, Warszawa 2006, s. 353-367.

Kasprowicz Jan, Marchołt gruby a sprośny. Jego narodzin, życia i śmierci misterium tragikomiczne w obrazach czterech zamknięte, w: tenże, Pisma zebrane, wyd. krytyczne pod red. J.J. Lipskiego i R. Lotha, t. VI: Utwory literackie 6, Wydawnictwo Literackie, Kraków 2002.

Kasprowicz Jan, Pisma zebrane, wyd. krytyczne pod red. J.J. Lipskiego i R. Lotha, t. I-VI, Wydawnictwo Literackie, Kraków 1973-2002.

Kasprowiczowa Maria Janowa, Dziennik, Wydawnictwo Domu Książki Polskiej, Warszawa 1932-1934.

Kołaczkowski Stefan, Wyspiański. Kasprowicz. Przeglady, oprac. S. Pigoń, Państwowy Instytut Wydawniczy, Kraków 1968.

Nietzsche Friedrich, Niewczesne rozważania, przeł. L. Staff, nakł. Jakóba Mortkowicza, Warszawa-Kraków 1912.

Podraza-Kwiatkowska Maria, Wolność i transcendencja. Studia i eseje o Młodej Polsce, Wydawnictwo Literackie, Kraków 2001.

Podstawka Anna, Świat, który się nie kończy. Człowiek i transcendencja w teatrze Jana Kasprowicza, Wydawnictwo KUL, Lublin 2014.

Podstawka Anna, Teatr religijny Jana Kasprowicza, w: Dramat i teatr religijny. Wyróżniki i paradygmaty. W stulecie urodzin Profesor Ireny Stawińskiej, red. W. Kaczmarek, J. Michalczuk, Wydawnictwo KUL, Lublin 2014, s. 227-244

Rzewuska Elżbieta, Misterium i moralitet w polskim dramacie międzywojennym, w: Dramat i teatr religijny w Polsce, red. I. Sławińska, W. Kaczmarek, Towarzystwo Naukowe KUL, Lublin 1991, s. 287-328.

Sosnowski Mirosław, Światopogląd Jana Kasprowicza. Elementy i fazy rozwoju, w: Pro memoria. Jan Kasprowicz w osiemdziesiąta rocznicę śmierci, red. M. Sosnowski, G. Igliński, Polskie Bractwo Kawalerów Gutenberga, Warszawa 2006, s. 21-207.

Stala Marian, Człowiek z właściwościami. (W kręgu antropologicznej problematyki Młodej Polski), w: Stulecie Młodej Polski, studia pod red. M. Podrazy-Kwiatkowskiej, Universitas, Kraków 1995, s. 135-152.

Truskolaska Anna, Młodopolska ekspansja pojęcia „misterium”, w: Wśród mitów teatralnych Młodej Polski, red. I. Sławińska, M.B. Stykowa, Wydawnictwo Literackie, Kraków-Wrocław 1983, s. 277-308.

Tuczyński Jan, Kasprowicz. Pogłos wieczności, Oficyna Wydawnicza „Nirwana”, Bydgoszcz 1996. Wasilewski Zygmunt, Jan Kasprowicz. Zarys wizerunku, Gebethner i Wolff, Warszawa [1923]. 
Anna Podstawka

\title{
Antinomies of human condition in Marcholt by Jan Kasprowicz
}

\begin{abstract}
(Summary)
Marcholt occupies an individual position in the literary output of Jan Kasprowicz. This drama was created in stages during a couple of years' time, being entirely published only in the year 1920; wholly absorbing the artist until the end of his life. The multidimensional issue layer of the work was subordinated to a dramatic convention of mystery and is formed in the style of a morality play, with typical for the end of the $19^{\text {th }}$ and the beginning of the $20^{\text {th }}$ centuries, syncretic treatment of medieval religious theatres. An intrinsic key to deciphering Marchott is to treat it as a synthesis of outlook changes and of the poet's dilemmas, as an attempt of holistic presentation of the antinomies prescribed to the human condition. Kasprowicz constantly wrestled with the mystery of human existence, with characters' vocation and with their life tracks since birth until death, pinpointing human inborn creation towards good and people's plunging into sin, the spiritual and corporeal nature, the desire for freedom and entangling in illusions of happiness. He did not manage, however, to fully realize his drama inspirations and theatrical ambitions, in a „tragico-comic mystery" about Marchołt stopping halfway, signaling the direction of trespassing pessimistic and decadent anthropology. The true reconciliation will take place only in the poetic Book of the Poor (Księga ubogich), finding its completion in My world (Mój świat). Since the creation of Marchołt model, he tightly clings to rationalism of the contemporary civilization, being unable to accept its finiteness, the poet evolves affirmation of life synchronizing with nature, reconciling with himself and God, finding the long-awaited harmony of the universe.
\end{abstract}

Słowa kluczowe: dramaturgia Jana Kasprowicza; modernizm; antropologia chrześcijańska

Keywords: dramatic works of Jan Kasprowicz; modernism; Christian anthropology 